\title{
Public and Private Organizations: How Different or Similar are They
}

\author{
Anisur Rahman Khan \\ and Shahriar Khandaker* \\ East West University \\ Dhaka-1212, Bangladesh
}

Received 18.05.2016, received in revised form 24.07.2016, accepted 20.08.2016

\begin{abstract}
In spite of a growing body of research attempting to draw distinctions between public and private organizations over the years, it remains a disputable issue yet to be settled by organizational theorists and scholars alike. No conclusive understanding regarding the similarities and differences has been availed, and the scholarly discussions between these two types of organizations predominantly ended up finding out differences rather than similarities. Given the background, this paper attempts to ascertain the similarities and differences between public and private organizations based on the application and relevance of some important organizational concepts drawing on literature review as well as researchers' application of reflexivity in investigating the issues. The concepts that have been used and analyzed include goals, goods and services, resource ownership, structure, culture, leadership and managership, decision making. This analysis indicates that despite manifestation of diverse variations between public and private organizations, in some cases/aspects they do share common attributes. For example, it is assumed that bureaucracy is the most dominant feature in public organizations, but such model is also being followed by many big private organizations. On the other hand, private managerial practices and structural components are also being adopted by public organizations. Further empirical research or case study could be conducted/developed using the concepts used in this analysis concerning the similarities and differences between these two types of organizations in order to grapple a concrete understanding about organization as a whole. At the same time, it is also suggested to minimize the gaps between public and private organizations by sharing the best practices of each other for greater developmental requirements.
\end{abstract}

Keywords: Public, private, organization, similarities, differences.

DOI: 10.17516/1997-1370-2016-9-12-2873-2885.

Research area: politology.

\section{Introduction}

As one of the most dominant institutions of modern society, organization exerts a tremendous influence on our lives. We obtain a large measure of our cultural, social and material satisfactions from organization (Bedeian \& Zammuto, 1991).

Over the years, increasing attention has been paid to searching for the similarities and differences between public and private organizations, and there is a growing body of literature on the

(C) Siberian Federal University. All rights reserved

* Corresponding author E-mail address: khanpatc@gmail.com; skhandaker@gmail.com 
issue (Perry \& Rainey, 1988). The similarities and differences between the public and private sectors have frequently been debated over in the literature on public administration, politics and economics (Boyne, 2002). Works of many scholars have confirmed that both public and private organizations differ in some obvious ways (Rainey, 2009). At the same time, some scholars hold the opinion that every organization, either public or private, is similar in some important respects (Murry, 1975, Boyne, 2002). Although many different interpretations and perceptions have been attained, a clear understanding of public and private organizations is yet to be established (Fottler, 1981).

It can be mentioned that classical scholars who developed organization theories never proposed their approaches/sciences considering differences between these two types of organizations. Noticeably, they came up with certain prescriptions concerning organizational design in a manner that can be uniformly possessed and systematically used by both types of organizations in order to function properly (Marume, Jubenkanda, \& Namusi, 2014). Later on, the importance to embrace the "proven" private sector management style/tools and practices of public organization was further realized to cope with the environment and to become more flexible (Hood, 1991). Meaning that both organizations can realistically share and practice common attributes. Such advancement proves that the demarcation boundary between the public and private sectors is disappearing (Mitchell, 2003). Nonetheless, as the debate concerning the similarities and differences between public and private organizations seems to continue to grow in future, there are opportunities to expand our knowledge and enrich the discipline of "organization" significantly. At this juncture, in this paper, through a rigorous review of the literature and reflexive interpretation, attempts have been made to analyze the distinctiveness and similarities between these two types of organizations exclusively by taking into consideration the relevance and application of some relevant and important concepts. In this review, a pure governmental bureaucratic agency, a governmental profit oriented corporation and a governmental service agency are referred to as a public sector organization, and a profit business firm is referred to as a private sector organization. Specific examples in relation to the analysis have been drawn from the context of Bangladesh. It is because of the fact that the researchers are based in Bangladesh and have a better understanding of the country and its context.

\section{Public \& Private Organizations: Searching for Differences and Similarities}

The similarities and differences of both organizations have been drawn and analyzed based on certain basic concepts of organization that include goals, goods and services, resource ownership, organization structure and design, leadership and managership, decision making and organization culture. The reason to apply these concepts and exclude others is that these concepts are very fundamental to the organization analysis and have greater applicability over other concepts in pursuance of understanding the features of public or private organizations in a systematic manner.

\section{Goals of public and private organizations}

Every organization has a purposeful system; they exit to achieve certain goals (Buenger, Daft, Conlon, \& Austin, 1996). Organizational goals are what an organization seeks to achieve its existence and operation (Bedeian \& Zammuto, 1991).

Scholars suggest that private and public organizations differ significantly in terms of 
goals or goal attainments. It is argued that public agencies have distinctive goals, such as equity and accountability, that are absent in the private sector (Ferlie et al., 1996; Flynn, 1997 quoted in Boyne, 2002) Public sector organizations are controlled predominantly by political forces, and not by market forces, the goal differences between these two organizations are an obvious phenomenon. It is perhaps little difficult to find out the similarities in this regard because both organisations hold two different ideologies and are controlled by those ideologies. Public organization goals are controlled by political factors, and private organisation goals are dominated by the market forces. One of the interesting anomalies concerning the comparison between public and private organizations are the goal complexity and ambiguity (Rainey \& Bozeman, 2000). Private organisations pursue a single goal of profit (Farnham \& Horton, 1996 quoted in Boyne, 2002). Public organizations, on the other hand, have relatively vague, intangible and multiple goals (Allison, 2012). Public organisations are exposed to more external scrutiny and accountability and their goals are often conflicting or confronting (Perry \& Rainey, 1988).

Nonetheless, there are some obvious areas where the goals of public and private organizations can align together. For example, many public corporations/industries are designed for profit making pursuance and making a contribution to economic development of the country. The activities of profit-oriented public and private organizations can be fit into "resource dependence theory" as they are dependent on the environment for external resources and adopt appropriate management strategies considering the criticality and scarcity (Hatch, 2013). Public and private sector banks, industries and airlines are some of the good examples that need resources from the environment and compete with other organizations for resources.

\section{Goods, services and resource ownership}

Goods and services of a public organization are different from the goods and services of the private organization. The goods and services of privateorganizationsdependonthemarketsituation and follow the demand and supply mechanism. Private goods and services are excludable and rival in nature. Public organizations confront the minimal threat from their rivals for the provision of their goods and services. They do not operate in a competitive market. Even when competition is present, public organizations frequently enjoy a dominant position (Boyne, 2002). The non-rivalry characteristics of public goods and services might bring a free-rider problem. People who consume goods but do not bear the burden are called freeriders. Understandably, the free rider issue is a serious problem for a public organization, but the nature of a private organization never allows such problem to arise.

For some scholars, the main conventional distinction between public and private organizations is their resource ownership (Rainey, Backoff, \& Levine, 1976). Private organizations maintain a distinguishable ownership, but it is difficult for public organizations to identify owners of resources. Public ownership cannot be transformed into individuals (Perry \& Rainey, 1988). Conversely, private ownership can easily be transformed into individuals. Private firms are owned by the entrepreneurs or shareholders who own the property and resources and receive direct monetary benefits (Booney, 2002).

Notably, the dominance of the public sector organizations in the provision of public goods and services does not necessarily mean they can overlook or underestimate their counterparts. Many goods and services that are traditionally being delivered by the public sector such as transportation, telephone, health, education and so on are also being delivered by the private sector. 
"Public-private partnership" and "contracting out to private sector" have become phenomenal in recent times in delivering public services. Involving private sector in the state ownership or delivering of public services is a global trend now (Baisely \& Ghatak, 2001). In Bangladesh, for example, realizing the importance of public-private partnership for development, a new agency named "Public-Private Authority (PPA)"was formed in 2010 in order to promote joint activities and ownership design through the public and private sector partnership in various sectors. Prime Minister's Office of Bangladesh is directly monitoring the activities of PPA.

It is often difficult to identify the ownership of resources for public organizations. Nonetheless, in some cases, ownership of public organizations is similar to private organizations. For example; many big public organizations such as British Airways, Thai Airways have shares in the market. In Bangladesh, public corporations doing business in different sectors such as jute, banking, textile, fertilizer, sugar, etc. have market shares. Such types of public limited agencies are in a constant competition with private sector agencies for their survival.

\section{Organization structure}

Organizational structure focuses on the division of labour of organization members into a number of distinct tasks. The structure helps to coordinate all the tasks to accomplish the mission and goals of that organization in a unified way (Minzberg, 1980). Classical organization theorists such as Max Weber, Henry Fayol, Fredrik Taylor and Luther Gulick attempted to design the most effective and efficient way of achieving the organization mission and goals through structural arrangements of people, positions and work units (Hatch, 2013). The prescriptions embedded in classical theories are relevant to and widely practiced by many private and public organizations. Weberian bureaucracy such as division of labour, hierarchy of authority and formalised rules and procedures are not only found in most governments, but also nearly in every university and large private organizations (Hatch, 2013). Weber himself claimed that his analysis can be equally applied to both government agencies and private business firms (Rainey, 2009). Civil/ public service around the world is the most pertinent example which follows the Weberian principles of bureaucracy. Morgan (1997), on the other hand, opines that some organizations (private) have had tremendous success using the mechanistic model of organization proposed by classical theorists. In this connection, he also cited examples of McDonald and other similar firms in the fast food industry that follow the Tayloristic principles of scientific management in structuring and designing organization. At the same time, Gulick's exponents of the scientific administration [POSDCORB, $\mathrm{P}=$ planning, $\mathrm{O}=$ organizing, $\mathrm{S}=$ staffing, $\mathrm{D}=$ directing, $\mathrm{CO}=$ coordinating, $\mathrm{R}=$ reporting and $\mathrm{B}=$ budgeting, for example] is a common field of public and private organizations. Both public and private organizations have their own mechanisms of practicing POSDCORB through reflection in the structure and design (Marume, Jubenkanda, \& Namusi, 2014). Fayol, a classical administrative scholar who is best known as proposing administrative principles, said that administrative principles are not only applicable to public organizations, but also can be equally undertaken by the private agencies (Marume, Jubenkanda, \& Namusi, 2014).

On the other hand, one of the major criticisms of classical theories is that such mechanistically designed organizations face difficulty in changing circumstances as they are only designed to achieve pre-determined goals with the least focus on innovation (Morgan, 1997). At this backdrop, since the 1960 s, modern theories of organization evolved with the idea that 
organization is comparable with a living organism and suggest for balancing between internal and external pressures, developing core competencies and striving for achieving maximum efficiency in changing environment (Hatch, 2013). Such an organic perspective is concerned with survival, organization-environment interface and organizational effectiveness (Morgan, 1997). Burns and Stalker (1961), in this respect, suggest that effective organization design is based on fitting the internal organization structure into the demands of the environment (Hatch, 2013). Lawrence and Lorsch (1967) further argue that successful organizations meet the demand of environment through a degree of differentiation and means of integration and communication (Hatch, 2013). The distinctions between mechanistic/classical and organic/modern structure of organization are as follows:

A mechanistic structure is regarded as an old and the dominant fashion of public organization, whereas, an organic structure is mostly associated with a private organization. Mechanistic organizations tend to perform better in a stable environment while organic organizations tend to perform better in an unstable environment (Morgan, 1978). Most public organisations work in a stable environment, but private organisations work in an unstable competitive market environment. Nonetheless, it does not necessarily mean that public organizations can solely rely on mechanistic design or principles. Public organizations worldwide are undergoing major or minor structural reforms on a continuous basis and adopting similar governing principles as those seen in the private sector. For example; New Public Management (NPM), a generic form of the public organization reform, embraces copying or adopting the private sector managerial practices into public sector management (Box, 1999, Hood, 1991). In this sense, structural and managerial practices of the private sector are also being used in public sector as they bear commonalities in many respects.

It should be noted that since the 1960s many studies have focused on excavating the characteristics of organization structures and designs. An important study conducted by Henry Mitzberg (1980) that divides an organization into five basic parts, such as an operating core, a strategic apex, a middle line, a techno-structure and support staff. The structural configuration of such an organization follows some key elements, such as simple, machine bureaucracy, professional bureaucracy, divisionalized form and adhocracy.

According to some scholars, all the elements of this design are relevant to both public and private sector. For example, a simple structure is appropriate for small public companies, small corporations and new government departments. Machine bureaucracy is appropriate for companies that work with mass production, large government

Table 1. Mechanistic \& Organic Structure of Organization

\begin{tabular}{|l|l|}
\hline \multicolumn{1}{|c|}{ Mechanistic Structure } & \multicolumn{1}{c|}{ Organic Structure } \\
\hline High horizontal and vertical differentiation & High complex horizontal and vertical integration \\
\hline High formalisation & Low formalisation \\
\hline Centralisation & Decentralisation \\
\hline Standardization & Joint problem solving and interaction \\
\hline Close Supervision & Personal expertise \& creativity without supervision \\
\hline Vertical communication & Horizontal communication \\
\hline
\end{tabular}

Source: Daft (2001); Hatch (2013) 
organisations and even private companies that work in a stable environment. Professional bureaucracy is appropriate for private companies or public organizations working in a complex and stable environment. The divisionalized form is appropriate for companies that work in a complex and unstable environment, and adhocracy is appropriate for companies that work in a turbulent situation (Lunenburg, 2012 \& Hatch, 2012). Mitzberg's influential structural categorization clearly indicates that both public and private organizations often share same structural forms in their day to day operations.

\section{Decision Making}

Decision making in an organization is basically defined as identifying and solving problems from a variety of alternatives. It can occur in response to a problem, or it may relate to a desire to increase effectiveness or innovate. Etzioni (1967) defines decision making as an element of choice and as the most deliberate aspect of social conduct. It is a set of specific commitments to one or more specific courses of action. There are many approaches of decision making in organizations. The rationalistic model has a widely held conception in the decisionmaking process. In this model, a decision maker becomes aware of the problem, posits a goal, carefully assesses the possibilities of all the consequences, evaluates each set of consequences and chooses among them according to his/her estimates of their respective merits with reference to the state of affairs he/she prefers (Etzioni, 1967, Allison, 1971). Alternatively, bounded rationality describes a method of decision that has to be made under severe time and resource constrains (Daft, 2001). An incremental model is based on a marginal or gradual change. In the incremental model, a decision-maker focuses only on those policies that differ incrementally from the existing policies. In this model, relatively small numbers of policy alternatives are considered, only a few "important" consequences are evaluated, a problem is continuously redefined, and there is no best solution. It is mostly remedial to present social imperfection (Lindbom, 1959 quoted in Etzioni, 1967). In a garbage can model, decision opportunities are viewed as fundamentally ambiguous stimuli. A decision is an outcome or interpretation of several relatively independent streams within the organisation namely problems, solutions, participants and choice opportunities that exist quite independently from each other (Cohen, James, \& Olsen, 1972).

Incrementalism is best suited for an organization in a stable environment where routine is the best policy (Bedeian \& Zammuto, 1991). Public organizations usually perform routine based activities, and they mostly debunk on incrementalism. The government budget is the best example as such, which is mostly based on addition or deduction on the previous budget. Most of the private organizations work in an unstable, competitive and turbulent environment. Therefore, decisions in private organizations are often based on rational thinking because they need to consider all the constraints and opportunities in a logical way in running the business and tackle the market forces. The garbage can model of decision making was based on the idea of organized anarchy. Organized anarchy describes organizations characterised by a rapid change and a non-bureaucratic environment (Daft, 2001). In such circumstances, the garbage can model appears to best fit in private organizations. When innovation is a concern for an organization and when it requires adapting the changing circumstances, the garbage can model of decision making in these cases offers appropriate solutions. However, it is difficult to conclude what types of decisions an organization should follow. According to some scholars, as it is difficult to be fully rational, decision makers 
follow the principles of bounded rationality. In the context of complex or serious situations, public organizations certainly follow the rational model. For example, it is impossible for a government bureau to construct a bridge over a big river unless it is feasible in all respects. In this case, it requires following every single prescription of the rational model. Incrementalism, on the other hand, can be easily practiced by both types of organizations when the decision point does not require a critical analysis.

\section{Organisation Culture}

Culture is a set of values, guiding beliefs, understandings and ways of thinking that are shared by members of an organization and taught to new members as the correct way to think, feel and behave (Daft, 2001). Culture provides members with a sense of organizational identity and generates a commitment to beliefs and values. When these ideals and values lead to success, they become institutionalized, and an organizational culture emerges. Every organization, irrespective of region, country or sector, has a culture of its own (Russu, 1989 quoted in Ras \& Russu, 2015).

Culture performs two critical functions in organizations: (1) integrates members so that they know how to relate to one another, and (2) helps the organizations adapt to the external environment(Daft, 2001). Organizationsinfluence the local, regional and national cultures to which they contribute and sometimes organizational culture clashes with the culture of place where it locates (Hatch, 2013). Organizational cultures are embedded in and shaped by national cultures. For example, scholars have identified several differences between Russian and US business ethics (Puffer and McCarthy 1995 quoted in Fey \& Denison, 2003). Giving bribes and ignoring rules are more acceptable in Russia than in the United States, while whistle-blowing on fellow workers, having large salary differentials and terminating people are more acceptable in the United States than in Russia (Fey \& Denison, 2003).

The most distinguishable feature of a successful organisation is its culture, and for that it may enjoy competitive advantage over other organizations. Companies like Coca-Cola, Disney, General Electric, Intel, McDonald's, Microsoft and Toyota have developed a distinctive and influential culture (Cameron \& Quinn, 2011). In many countries, Coca-Cola has changed a drinking habit of people; McDonald's has changed a food habit of people. Constructing or redirecting such type of changes is hardly possible for public organizations, since public organizations cannot readily change its operational norm, which might lead to shaping or reshaping people's behaviour or patterns of consumptions. Unfortunately, traditional organizational cultures in the public sector are likely to impede public service modernization and innovation (O'Donnell, O., \& Boyle, 2008).

Contemporary public sector organisations have been forced to change their organization cultures. Many examples can be cited from Bangladesh. One of such an example is that in the erstwhile undivided Indian (Bangladesh, India \& Pakistan) Civil Service, the principal operating norm(although unwritten, buta dominant practice) for the civil servants was to consider themselves as masters of the people and maintain distance from the public. But today's Bangladesh Civil Service (successor) has shifted its focus from rigidity to flexibility, and members of Civil Servants are being trained in a manner so that they have better interface with the citizens. In reality, there is a cultural change in Bangladesh civil service due to demands of the external environment. Civil servants are now also working in partnership with the private sector in many development areas. Understandably, when the members of public and private sectors work together, they share and practice each other's culture. This is 
how many managerial practices are evident in the public sector organizations. The customer service movement of the 1980's and 1990's has largely infused the drive of a cultural change into the management of public organizations. As such it can be stated that although there are differences in organizational cultures between the public and private sector organizations, both the public and private sector can also share similar organizational cultures in some obvious ways. Culture is the key battleground in the context of the management reform in the public service. Therefore, it is suggested that the old bureaucratic culture of the public service must be dismantled and replaced by a more private sector like entrepreneurial culture (O’Donnell \& Boyle, 2008).

\section{Leadership and Managership}

Leadership as a subject has been defined in so many different ways and from various perspectives. Leadership can be defined both as a process and a property. It is a process in terms of coordinating activities, and as a property it is regarded as a set of qualities of leaders, such as personality, characteristics, motives, skills and abilities (Jago, 1982). The behavioural approach to leadership, on the other hand, distinguishes effective leaders by their behaviours in the event of interacting with followers. Contingency view of leadership largely depends on situations. It is concerned with specifying the conditions or situations under which certain leadership traits and behaviours are effective (Jago, 1982) However, there is no best way to lead people. As leaders in private organisations face many unstable and turbulent situations/environment they need what is called by Yukl (1994) - "strategic leadership." Leaders in the private sector can emerge in response to the situation/environment, but it is difficult for public sector leadership. Laws, rules, and oversight activities take away more discretion from leaders in the public sector than from leaders in the private sector (Hooijberg \& Choi, 2001). As a matter of fact, the public sector leaders have less autonomy in exercising leadership than the private sector managers do (Hooijberg \& Choi, 2001).

Public mangers/leaders are dictated by political necessities and often seek to mediate decisions in response to a wide variety of pressures and put together a coalition of inside and outside groups to survive. They are subject to scrutiny by legislative and judiciary that, in turn, stand as a hindrance to perform their executive and administrative tasks with complete freedom (Allison, 2012). They have limited decision-making autonomy, greater reluctance to delegation and fragmented authority over subordinates (Allison, 2012). Although it is argued that public managers/leaders have a strong desire to serve the people and are less materialistic than private managers (Booney, 2002), there is rarely any bottom line for them (Allison, 2012). On the contrary, private managers take a longer time perspective towards organization building and market development. The top private managers have a longer tenure in the office and often develop successors. The performance of private managers/leaders is measured by performance. They have considerably greater authority in managing the subordinates. They are not chained by legislative or judicial discretions. Their bottom line is profit, market performance and survival (Allison, 2012). They are more materialistic, performance oriented and driven by desire of their firms to meet the demands of the customers (Boyne, 2002).

There are fundamental differences between leadership and managership. Managers are concerned about how things get done. Leaders are concerned with what things mean to people and they try to get people to agree about the most important things to be done (Yukl, 1994). Managerial goals arise out of necessities rather 
than desires and deeply embedded in the organizational culture. Managers embrace work as a process. They negotiate, bargain and also use rewards, punishments and other forms of coercion (Zaleznik, 1977).

As for the similarities, both types of organizations need both a manager and a leader or someone who has both leading and managing skills. Leadership and management are two distinctive but complementary systems of action and are compulsory for success of an organization (Yukl, 1994). While managers do stable, rulesbased functions, leaders perform non-routine, adaptive, creative and challenging functions. Nonetheless, the private sector managers are broadly driven by profit goals, while the public sector managers are broadly accountable to a public opinion and face many legal and political constraints to accomplish their tasks (Rainey et al., 1976). The success of a manager in modern organizations necessarily involves leadings as well. Many large-scale private organizations have become global leaders due to high standard leadership and managerial capabilities of the top executives that are very unlikely for public organizations. The scarcity of effective leaders is a critical problem in a private organization. Public executives tend to be more of managers than leaders. Realizing the need for an ideal leader and manager many financial and service providing public corporations/ agencies in Bangladesh have adopted polices to allow lateral entry or direct recruitment at the top positions from the private sectors. One of the reasons for adopting such polices is to address the leadership and managerial crisis in the public sector.

Discussion about leaders and mangers clearly indicates that it is comparatively easier for public executives to act as managers than that of leaders. Again, demonstration of leadership is easier in private organizations since they have wider scopes in practising leadership. But in order to run an organization successfully, the requirement for both leaders and managers is imperative.

\section{Conclusion}

In the long last, it can be stated that there is a number of sharp differences along with similarities between public and private organizations in terms of goals, goods, services and resource ownership, organization structure, decision making, culture and leadership. Over the years, the demarcation of a clear-cut boundary between the public and the private sector has received a good deal of academic interests. This review and interpretative analysis confirm the existence of uniqueness and diversities of both public and private organizations. Although public organizations traditionally do not operate in a competitive market same as private organizations and are largely chained by legal, economic and political bindings, today, due to internal and external pressures, the public organizations have been forced to undergo structural and procedural changes and have undertaken many practices used by private organizations. Public organizations are also working in partnership with private organizations. All these changes are bringing public and private organizations closer minimizing their gaps and helping to create a new form of organization called a "hybrid" organization (Mitchell, 2002). The hybrid organization serves the purposes of both private and public organizations under a single framework.

However, in order to understand an organization as a social entity, there is a definite need to analyse public and private organisations in a binary notion. After this analysis, perhaps, it would be difficult to directly disregard public and private organizations as diametrically opposite; on the contrary there are many pieces of evidence that might confirm that in some obvious ways these two organizations are similar. Public and 
private organizations can be considered as two sides of the same coin. If we really want to analyse a coin, we have to analyse both of its sides.

One of the major limitations of this analysis is that it is not empirically tested. Nonetheless, it does not reduce the importance of this analysis; it rather has the potential to provide some strategic directives for researchers. For this analysis, it is now possible to easily find out variables that can be taken up for empirical testing or developing by future researchers and contribute to the theoretical development of the "organization" discipline. Finally, both public and private sectors have much to learn from each other, must share ideas, management and technologies for the greater developmental interest of the country they are operating in. They should neither be competitors nor have a tendency to dominate each other. In order to promote the scopes for sharing, scholars need to learn both types of organizations and suggest procedures on how to bring them closer by minimizing the gaps.

\section{Reference}

Adams, G.B., \& Balfour, D. L. (2012) Unmasking Administrative Evil: Searching for a Basis for Public Ethics. In J. M. Shafritz \& A. C. Hyde (eds), Classics of Public Administration (17 ${ }^{\text {th }}$ edt). Boston: Wadsworth.

Allison, G. T. (1971). Essence of Decision: Explaining the Cuban Missile Crisis. Boston: Little Brown.

Allison, G.T. (2012). Public and Private Management: Are They Fundamentally Alike in All Unimportant Respects. In J. M. Shafritz \& A. C. Hyde (eds.), Classics of Public Administration (17 ${ }^{\text {th }}$ edt). Boston: Wadsworth.

Antonsen, M., \& Jorgensen, T. B. (1997). The "Publicness" of Public Organizations. Public Administration, 75 (2): 337-57.

Besely, T., \& Ghatak, M. (2001). Government Versus Private Ownership of Public Goods. The Quarterly Journal of Economics, November: 1343-1372

Bedeian, A. G,. \& Zammuto, R. F. (1991). Organisations: Theory and Design. Hinsdale, IL: The Dryden Press.

Boyne, G. A. (2002). Public Private Management: What is the Difference? Journal of Management Studies, 39 (1): 97-122.

Buenger, V., Daft, R. L., Conlon, E. J., \& Austin, J. (1996). Competing Values in Organisations: Contextual Influences and Structural Consequences. Organisation Science, 7(5): 557-576.

Cohen, M. D., James G. M., \& Olsen, J. P. . (1972). A Garbage Cane Model of Organisational Choice. Administrative Science Quarterly, 17 (1): 1-25.

Daft, R. L. (2001). Essentials of Organisation Theory and Design ( $\left.2^{\text {nd }} e d\right)$. Cincinnati: SouthWestern.

Daft, R. L. (2010). Understanding the Theory and Design in Organisation [10th edt]. Australia: South-Western.

Dean, James W. Jr., Yoon, Se Joon \& Susman, Gerald I. (1992). Advanced Manufacturing Technology and Organisation Structure: Empowerment or Subordination? Organization Science, 3 (2): 203-229.

Dunleavy, P., Margarets, H., Bastow, S. \& Tinkler, J. (2005). New Public Management is DeadLong Live Digital-Era Governance, JPART, 16: 467-494. 
Etzioni, A. (1967). Mixed Scanning as a 'Third' Approach to Decision Making. Public Administration Review, 27: 385-392.

Etzioni, A. (1986). Mixed-scanning revisited. Public Administration Review, 46 (1): 8-14.

Everdingen, Y. M. v., \& Waarts, E. (2003). The Effect of National Culture on Adoption of Innovations. Market Letters, 14(3): 217-232.

Fey, C. F. \& Denison, D. R. (2003) Organisational Culture and Effectiveness: Can American Theory Be Applied in Russia? Organisation Science, 14 (6): 686-706.

Fottler, M.D. (1981). Is Management Really Generic? The Academy of Management Review, 6:1, pp. 1-12.

Hannan, M.T., \& Freeman, J. (1977). The Population Ecology of Organization, American Journal of Sociology, 38 (5): 926-964.

Hatch, M. J. and Cunliffe, A. L. (2013) Organisation Theory. Oxford: Oxford University Press.

Hickson, D. J., Pugh, D. S., \& Pheysey, D. C. (1969). Operations Technology and Organization Structure: An Empirical Reappraisal. Administrative Science Quarterly, 14 (3): 378-397.

Hood, C. (1991). A Public Management for All Seasons. Public Administration, 69: 3-19.

Hooijberg, R., \& Choi, J. (2001). The Impact of Organisational Characteristics on Leadership Effectiveness Model: An Examination of Leadership in Public and a Private Sector Organisation. Administration and Society, 33(4): 403-431.

Jago, A. G. (1982). Leadership: Perspectives in Theory and Research. Management Science, 28 (3): 315-336.

Levine, C., Backoff, R., Cahoon, A., \& Siffin, W. (1975). Organisational Design: A Post Minnowbrook Perspective for the "New" Public Administration, American Society for Public Administration. Public Administration Review, 35: 425-435.

Lewis, C. W., \& Gilman, S. C. (1991). The Ethics Challenge in Public Administration: A Problem Solving Guide. San Francisco: Josse-Bass.

Lindblom, C. (1959). The Science of Muddling Through. Public Administration Review, 19: 79-88.

Lunenburg, F. C. (2012). Organizational Structure: Mintzberg's Framework. International Journal of Scholarly, Academic and Intellectual Diversity, 14 (1): 1-8.

Marume, S. B. M., Jubenkanda, R. R., \& Namusi, C. W. (2014). Similarities and Differences between Public Administration and Business Administration. International Journal of Scientific Engineering and Research (IJSER), 4 (1): 41-44.

Mintzberg, H. (1980). Structure in 5's: A synthesis of the Research on Organisation Design. Management Science, 26 (3): 322-341.

Mitchell, S. M. (2002). Analyzing Differences between Public and Private Sector Information Resource Management: Strategic Chief Information Officer Challenges and Critical Technologies. Master's Thesis, Air Force Institute of Technology, Ohio University:

Morgan, G. (1997). Images of Organisation. Thousand Oaks: Sage.

Murray, M. (1975). Comparing Public and Private Management: An Exploratory Essay. Public Administration Review, 35:364-371.

Nutt, Paul C. (1998) Framing Strategic Decisions. Organisation Science, 9(2): 195-216.

O’Donnell, O., \& Boyle, R. (2008). Understanding and Managing Organisational Culture. Institute of Public Administration: Dublin. 
Ostrom, E.(2003). How Types of Goods and Property Rights Jointly Affect Collective Action. Journal of Theoretical Politics, 15 (3): 239-270.

Perry, J. L. \& Rainey, H. G. (1988). The Public Private Distinction in Organisation Theory: A Critique and Research Strategy. Academy of Management Review, 13(2): 182-201.

Priem, R. L., \& Rosenstien, J. (2000). Is Organsiation Theory Obvious to Practitioners? A Test of One Established Theory. Organisation Science, 11(5): 509-524.

Rainey, H.. G., Backofff R. W., \& Levine, C., H. (1976). Comparing Public and Private Organizations. Public Administration Review, 36: 233-44.

Rainey, H. G. (2009). Understanding and Managing Public Organisation. John Willy \& Sons: San Francisco.

Ras, M., \& Russu, D. C. (2015). The Organizational Culture in Public and Private Institutions. Procedia - Social and Behavioral Sciences, 187: 565 - 569

Savas, E. S. (1982) Privatising the Public Sector. Chatham, NJ: Chatham House.

Ykul, G.A. (1994). Leadership in Organisation. Englewood Cliffs, N.J.: Prentice-Hall.

Zaleznik, A. (1977). Managers and Leaders: Are they Different? Harvard Business Review, 55: 67-78.

\title{
Государственные и частные организации: сходства и отличия
}

\author{
Анисур Рахман Хан, Шахриар Хандакер \\ Университет Восток-Запад \\ Дакка-1212, Бангладеш
}

\begin{abstract}
Несмотря на большое количество многолетних исследований по выявлению различий между государственными и частными организациями, эта тема до сих пор остается актуальной как для теоретиков, так и для практиков науки об организациях. Единого понимания в отношении сходств и различий так и не было достигнуто, а все научные дискуссии на эту тему в конечном итоге выявляют преимущественно различия между этими двумя типами организаций, нежели сходства. Принимая это во внимание, авторы данной статьи пытаются определить сходства и различия между государственными и частными организачиями на основе применения и актуальности некоторых важных организационных понятий, опираясь на литературные источники, а также используя рефлексивность в изучении данного вопроса. Проанализированные понятия включают в себя цели, товары и услуги, владение ресурсами, структуру, культуру, лидерство и администрирование, принятие решений. Данньй анализ показывает, что, несмотря на проявление разнообразных вариаций между государственными и частными организациями, в некоторых случаяхаспектах они имеют общие черты. Например, предполагается, что бюрократия наиболее доминантна в общественных организациях, но она также присутствует во многих крупных частных организациях. С другой стороны, некоторые частные управленческие практики и структурные компоненты также применяются государственными организачиями. Дальнейтие эмпирические или ситуационные исследования можно будет проводить/разрабатывать с применением понятий, используемых в данном анализе относительно сходств и различий между этими двумя типами организаций, чтобь сформировать конкретное понимание организации в целом. В то же время в статье предло-
\end{abstract}


жено минимизировать разрывы между государственными и частными организациями путем обмена передовым опытом друг друга.

Ключевые слова: государственный, частный, организация, сходства, различия.

Научная специиальность: 23.00.00 - политология. 